\title{
Pseudotumor cerebri caused by uncontrolled Graves' disease in an adolescent
}

\author{
Ashutosh Kumar, Sasikumar Kilaikode, Paul Saenger
}

\begin{abstract}
Introduction: Hyperthyroidism causing pseudotumor cerebri is very rare in children. Case Report: We are reporting a case of a 17-year-old girl with uncontrolled Graves' disease presenting with pseudotumor cerebri (PTC). Patient initially did not respond to common management of PTC with therapeutic lumbar puncture and acetazolamide, but improved after treating hyperthyroidism by radioablation therapy. Conclusion: We emphasize that uncontrolled hyperthyroidism should be suspected as a secondary cause of pseudotumor cerebri in children and treated aggressively to avoid its dreaded complications.
\end{abstract}

Keywords: Pseudotumor cerebri (PTC), Benign intracranial hypertension (BIH), Graves' disease, Papilledema, Radioablation therapy, Hyperthyroidism

$* * * * * * * * *$

Kumar A, Kilaikode S, Saenger P. Pseudotumor cerebri caused by uncontrolled Graves' disease in an adolescent. International Journal of Case Reports and Images 2013;4(12):702-704.

$* * * * * * * * *$

Ashutosh Kumar ${ }^{1}$, Sasikumar Kilaikode ${ }^{1}$, Paul Saenger ${ }^{2}$ Affiliations: ${ }^{1} \mathrm{MD}$, Resident, Pediatrics, The Brooklyn Hospital Center, Brooklyn, New York, USA; ${ }^{2} \mathrm{MD}$, Attending, Pediatric Endocrinology, The Brooklyn Hospital Center, Brooklyn, New York, USA.

Corresponding Author: Sasikumar Kilaikode, 539 85th Street Apt 1C, Brooklyn, New York, USA. 11209; Ph: 6466249458; Email: sak9072@nyp.org

Received: 24 April 2013

Accepted: 20 June 2013

Published: 01 October 2013
doi:10.5348/ijcri-2013-12-415-CR-9

\section{INTRODUCTION}

Pseudotumor cerebri (PTC), also known as benign intracranial hypertension (BIH), is a syndrome of increased intracranial pressure in the absence of change in ventricular size, with normal cerebrospinal fluid (CSF) analysis and normal neuroimaging [1]. Presenting symptoms are similar to those associated with hydrocephalus and typically include headache, vomiting, and changes in vision. Neurological examination is typically normal except papilledema which is almost always noted in adults, but may be inconsistent in children and adolescents.

Pseudotumor cerebri can be idiopathic or secondary to numerous underlying causes, including endocrine, rheumatologic, immunologic conditions and medications [1]. Both hypothyroidism and hyperthyroidism have been reported to cause PTC. Hyperthyroidism causing PTC is rare. There are only a few case reports of PTC caused by hyperthyroidism in adults and two case reports in the pediatric population $[2,3]$.

We are reporting a case of a 17-year-old girl with uncontrolled Graves' disease presenting with PTC.

\section{CASE REPORT}

A 17-year-old African-American female with congenital HIV controlled on anti-retroviral therapy (Complera, Gilead Sciences, Inc. Foster City, CA, USA), mild intermittent asthma and Graves' disease diagnosed five years ago, managed by methimazole with poor compliance, presented with one day history of severe pounding bi-frontal headache unrelieved by analgesics. There was no history of vomiting, fever, visual problems, weakness of extremities, seizures, neck stiffness, or trauma. On examination, patient had tachycardia and 
other vital signs were normal. Her weight was $48 \mathrm{~kg}$ and body mass index was $19.3 \mathrm{~kg} / \mathrm{m}^{2}$. Her physical examination showed diffuse enlargement of the thyroid gland and exophthalmos. On neurological examination, there was bilateral papilledema without any focal neurological deficit or altered sensorium. Computed tomography (CT) scan of head was normal. On lumbar puncture, her CSF opening pressure was raised $(430 \mathrm{~mm}$ of $\mathrm{H}_{2} \mathrm{O}$ ), no cells, with normal glucose and protein levels. The CSF was removed therapeutically which did not relieve her headache significantly. The CSF studies were negative for any bacteria, fungi, or viruses. Repeat magnetic resonance imaging (MRI) scan of brain with and without contrast was normal except for the finding of stable cerebellar tonsillar ectopia which was consistent with the previous MRI. Cerebral vascular thrombosis was ruled out by magnetic resonance venography (MRV) and magnetic resonance angiography (MRA) studies.

Blood analysis showed thyroid stimulating hormone (TSH) level <0.1 $\mu \mathrm{IU} / \mathrm{mL}$ (normal limits 0.35-4.94 $\mu \mathrm{IU} /$ $\mathrm{mL}$ ), $\mathrm{FT}_{4} 2.5 \mathrm{ng} / \mathrm{dL}$ (normal limits $0.9-1.5 \mathrm{ng} / \mathrm{dL}$ ), total $\mathrm{T}_{4} 17.7 \mu \mathrm{g} / \mathrm{dL}$ (normal limits $4.8-1.7 \mu \mathrm{g} / \mathrm{dL}$ ) and total $\mathrm{T}_{3}^{4} 310 \mathrm{ng} / \mathrm{dL}$ (normal limits 6o-160 $\mathrm{ng} / \mathrm{dL}$ ). Thyroid uptake study was consistent with diffuse toxic goiter with increased uptake $74.3 \%$ compared to the previous study $61 \%$.

Patient was initially treated with atenolol, acetazolamide and other supportive measures, which only partially relieved her symptoms. Patient received radioablation therapy with $15 \mathrm{mCi}$ of $\mathrm{I}-131$ and reported to feel better. She was followed up in pediatric endocrinology clinic one month after radioablation therapy and found to be asymptomatic. Her thyroid functions were slowly recovering (Table 1$)$.

Table 1: Changes in thyroid function test with treatment

\begin{tabular}{lccc}
\hline $\begin{array}{l}\text { Thyroid } \\
\text { Function Tests }\end{array}$ & $\begin{array}{c}\text { Prior to } \\
\text { Radioablation } \\
\text { therapy }\end{array}$ & $\begin{array}{c}\text { 4 weeks } \\
\text { after } \\
\text { therapy }\end{array}$ & $\begin{array}{c}\text { 6 weeks } \\
\text { after } \\
\text { therapy }\end{array}$ \\
\hline TSH $(\mu \mathrm{IU} / \mathrm{mL})$ & $<0.1$ & $<0.1$ & $<0.1$ \\
Total T4 $(\mu \mathrm{g} / \mathrm{dL})$ & 17.7 & 12 & 10.9 \\
Free T4 $(\mathrm{ng} / \mathrm{dL})$ & 2.5 & 1.7 & 1.4 \\
Total T3 $(\mathrm{ng} / \mathrm{dL})$ & 310 & 230 & 180 \\
\hline
\end{tabular}

\section{DISCUSSION}

Hyperthyroidism causing PTC is rare in children with only 2 reported cases $[2,3]$. In one report, hyperthyroidism was associated with hypovitaminosis A.

We excluded other causes of raised intracranial pressure in our patient and confirmed the diagnosis of
PTC. Although acetazolamide can cause symptomatic relief of PTC, our patient mostly improved after radioablation therapy of thyroid. Therefore, we concluded that PTC was associated with Graves' disease in this case. This was also supported by improvement in her thyroid hormone levels along with symptomatic relief.

The pathophysiologic basis of PTC is still not clearly understood, but a relationship has been established with elevated intracranial venous pressure $[4,5]$. The increase in resistance of CSF absorption is thought to be caused by an insufficiently high driving pressure gradient from the subarachnoid space to the venous system. Thyroxine, being a major regulator of sodium transport, can contribute to altered CSF dynamics [6]. The effect of thyroid hormone raising venous pressure may justify the association between those two entities [6].

\section{CONCLUSION}

We would like to emphasize that uncontrolled Graves' disease should be considered as a rare secondary cause of pseudotumor cerebri in children. Hyperthyroidism should be treated aggressively to reduce the complications associated with pseudotumor cerebri, most notably permanent visual impairment.

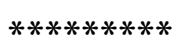

\section{Author Contributions}

Ashutosh Kumar - Conception and design, Acquisition of data, Analysis and interpretation of data, Drafting the article, Critical revision of the article, Final approval of the version to be published

Sasikumar Kilaikode - Conception and design, Acquisition of data, Analysis and interpretation of data, Drafting the article, Critical revision of the article, Final approval of the version to be published

Paul Saenger - Conception and design, Acquisition of data, Analysis and interpretation of data, Drafting the article, Critical revision of the article, Final approval of the version to be published

\section{Guarantor}

The corresponding author is the guarantor of submission.

\section{Conflict of Interest}

Authors declare no conflict of interest.

\section{Copyright}

(C) Ashutosh Kumar et al. 2013; This article is distributed under the terms of Creative Commons attribution 3.0 License which permits unrestricted use, distribution and reproduction in any means provided the original authors and original publisher are properly credited. (Please see www.ijcasereportsandimages.com/copyright-policy.php for more information.) 


\section{REFERENCES}

1. Rudolph CD, Rudolph AM, Lister GE, First LR, Gershon AA. Rudolph's Pediatrics, 22nd Ed. New York: McGraw-Hill Medical; 2011. P.2176.

2. Merkenschlager A, Ehrt O, Müller-Felber W, Schmidt $\mathrm{H}$, Bernhard MK. Reversible benign intracranial hypertension in a child with hyperthyroidism. J Pediatr Endocrinol Metab 2008 Nov;21(11):1099-1.

3. Roos RA, Van der Blij JF. Pseudotumor cerebri associated with hypovitaminosi A and hyperthyroidism. Dev Med Child Neurol 1985 Apr;27(2):246-8.
4. Skau M, Brennum J, Gjerris F, Jensen R. What is new about idiopathic intracranial hypertension? An updated review of mechanism and treatment. Cephalalgia 2006 Apr;26(4):384-99.

5. Bateman GA. Arterial inflow and venous outflow in idiopathic intracranial hypertension associated with venous outflow stenoses. J Clin Neurosci 2008 Apr;15(4):402-8.

6. Coutinho E, Silva AM, Freitas C, Santos E. Graves' disease presenting as pseudotumor cerebri: A case report. Journal of Medical Case Reports 2011;5:68.
Access full text article on other devices

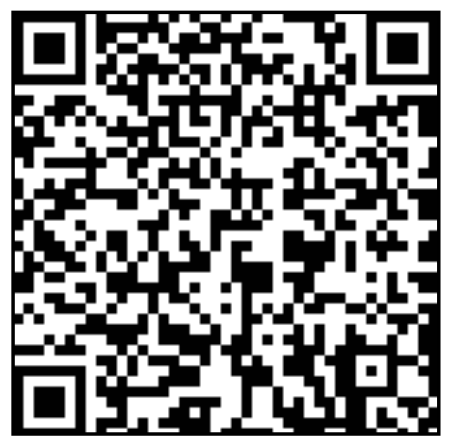

Access PDF of article on other devices

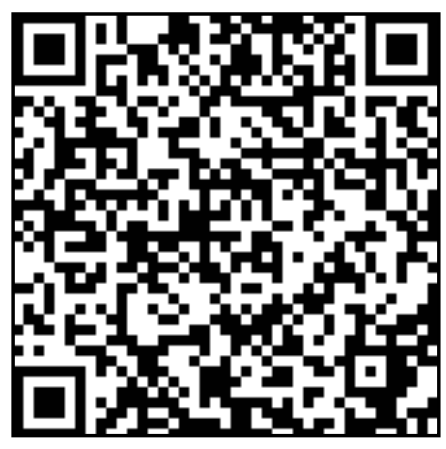

